\title{
Vláhová bilance - ukazatel vody v krajině
}

\section{JAROSLAV ROŽNOVSKÝ, FILIP CHUCHMA, ROSTISLAV FIALA, MOJMÍR KOHUT}

Klíčová slova: vláhová bilance - úhrny srážek - potenciální evapotranspirace - sucho

\section{SOUHRN}

Průběh počasí v posledních letech dokládá, že proměnlivost našeho počasí roste, a tím se také zvyšuje frekvence výskytu povodní, ale také sucha. Sucho bez ohledu na to, o jaký druh se jedná, znamená, že v naší krajině je nedostatek vody. Jde o to, jak nejlépe množství vody v krajině vyjádřit. Na brněnském pracovišti Českého hydrometeorologického ústavu v rámci výpočetního modelu AVISO v týdenním kroku vypočítáváme základní vláhovou bilanci (dále jen ZVB) pro travní porost, která je dána rozdílem mezi úhrny srážek a potenciální evapotranspirací. Výpočet je prováděn z denních hodnot doby slunečního svitu, teploty a vlhkosti vzduchu a rychlosti větru. Základem pro výskyt mimořádného sucha jsou nízké úhrny srážek a delší bezesrážková období, svưj vliv však mají i zvyšující se teploty vzduchu. Z analýzy vybraných roků s výskytem mimořádného sucha vyplývá, že deficitní hodnoty vláhové bilance se projevují v jednotlivých letech rozdílně, koncem vegetačního období dosahuje deficit i více jak 200 mm.

\section{ÚVOD}

Podnebí České republiky je typické svou vysokou proměnlivostí, která se $\checkmark$ posledních dvou desetiletích ještě zvyšuje. Výsledkem jsou také výskyty povodní i sucha, které se na našem území projevují nepravidelně. Změnám klimatu je přičítáno, že se zvyšuji četnosti výskytu extrémních stavů počasí. Jde o mimořádně vysoké úhrny srážek a následně výskyt plošných povodní v letech 1997, 2002 a díky rychlému tání vysoké sněhové pokrývky i v roce 2006. V roce 2010 byly zaznamenány vysoké srážkové úhrny a výskyt mnoha lokálních povodní z př́valových deštů. V posledních dvou desetiletích převažují stavy sucha, které jsou vyvolány nízkými úhrny srážek, hlavně během teplého půlroku (duben až záríi) s trváním od několika týdnů až po několik měsíců. Výskyty mimořádného sucha takřka na celém území ČR jsme zaznamenali v letech 2000, 2003, 2012, 2015 a 2017. Na jižní Moravě také v roce 2007. Je nutné připomenout, že výskyty sucha jsou u nás nahodilé, a proto je velmi obtížné jejich výskyt předpovídat. Tímto se stávají o to škodlivější, protože přicházejí neočekávaně v rưzných ročních obdobích.

Údaje o srážkách jsou zaznamenávány na srážkoměrných stanicích Českého hydrometeorologického ústavu (dále jen ČHMú), v posledních letech převážně na automatických stanicích [1]. Prưměrné úhrny srážek se z části liší podle období zpracování. V Atlasu podnebí Československa (1958) a Podnebí ČSSR - Tabulky (1960) jsou uvedeny výstupy zpracování za období 1901 až 1950. Mapy úhrnů srážek v Atlasu podnebí Česka [2] vyjadřují období 1961 až 2000. Střeštík a kol. [3] vyhodnotili úhrny srážek na území ČR za období 1961 až 2010 s výsledkem, že v dlouhodobém pohledu se průměrné roční úhrny srážek statisticky prokazatelně nemění, ale roste jejich dynamika. K hodnocení srážek za rưzná období, zvláště za roky s výskyty povodní či sucha najdeme vysoký počet publikací.
Srážkový deficit ve vegetačním období bývá velmi často doprovázen vysokými teplotami, včetně výskytu tropických dnů (maximální denní teplota vzduchu dosáhne či prekročí $30^{\circ} \mathrm{C}$ ), nižší relativní vlhkostí vzduchu, zmenšenou oblačností a vyšším počtem hodin slunečního svitu. Je známo, že úhrny srážek jsou jediným zdrojem vody pro naši krajinu. Ovšem přesto, že se používá k vyjádření sucha pouze úhrn srážek, není to zcela vhodná charakteristika.

Výskyty sucha jsou dány také hodnotami výparu [4]. Jde o složitý fyzikální proces a právě to je př́činou, proč na rozdíl od mnoha meteorologických prvků je měření výparu náročné [5]. Údaje o výparu, ovšem jen z vodní hladiny, máme ze sítě stanic Českého hydrometeorologického ústavu. Mimo tuto sít je jen několik stanic, většinou s účelovým zaměřením [6]. Ze srovnání např. s hodnotami evapotranspirace metodou FAO [7] vyplývá, že vztah není jednoznačný [8]. Pravidelné měření výparu z vodní hladiny zařízením GGI-3000 bylo v síti měřicích stanic zahájeno $v$ roce 1968, podobně na Slovensku [9]. V podstatě do roku 2011 byly př́stroje GGI-3000 nahrazeny automatickými výparoměry EWM [10]. Z vyhodnocení vyplývá, že úhrny výparu a jejich časová proměnlivost se v jednotlivých lokalitách dost liší, což je dáno proměnlivostí dalších meteorologických prvků [11]. Průměrný denní výpar z celé oblasti České republiky z období 1971-2000 činil 2,6 mm a průměrný úhrn za vegetační sezonu V-IX se rovnal 393,7 mm. Průměrný denní výpar z oblasti jižní Moravy z období 1981-2010 činil 3,0 mm a průměrný úhrn za vegetační sezonu V-IX se rovnal 462,3 mm [10, 12].

Bylo zjištěno, že roční dynamika výparu významně klesá s růstem nadmořské výšky, podobně jako dlouhodobé průměrné úhrny výparu, i když z tohoto pravidla existují výjimky způsobené dalšími činiteli, jako zeměpisná šířka nebo konkrétní lokální podmínky geografického prostředí. Během třicetiletí 1971-2000 pouze na dvou lokalitách sezonní úhrny výparu mají statisticky významné růstové trendy, a to $v$ Kroměřiži a v Holovousech. Zvyšování výparu se v těchto lokalitách projevuje v nárůstu 50 až 60 mm za 10 let, což je výrazná změna pro procesy v krajině [10]. Tento poznatek zcela neodpovídá zjištění, že průměrné teploty vzduchu mají statisticky prokazatelný nárůst [13].

S ohledem na náročnost a nákladnost měření výparu a jeho jednotlivých druhů jsou celosvětově použíány výpočty evaporace a evapotranspirace $[14,15]$. Právě evapotranspirace tím, že blíže vyjadruje výpar z porostů, lépe vyjadřuje celkový výpar z krajiny [16], ale je také součástí výpočtů závlahových dávek [15]. Pro určení výskytu či intenzity sucha využíváme zjednodušenou, v podstatě meteorologickou, vodní bilanci vyjádřenou vzájemným rozdílem úhrnů srážek a potenciální evapotranspirace. Označujeme ji jako základní (potenciální) vláhovou bilanci pro travní porost (dále jen ZVB_TP), která svými hodnotami umožňuje hodnotit také výskyty sucha v krajině [17]. Rozdíl mezi potenciální evapotranspirací a srážkami je ukazatelem pro hodnocení podoblastí v rámci agroklimatické rajonizace [18]. Taktéž je součástí výnosových modelů [19].

Obecně Ize říci, že množství vody v naší krajině je v prvním kroku dáno průběhem počasí, ale o jejím dalším výskytu významně rozhoduji vlastnosti našich půd, zvláště jejich retenční kapacita [20]. 


\section{MATERIÁL A METODY}

Meteorologické prvky naměřené na klimatologických stanicích jsou základem pro výpočty prováděné pomocí agrometeorologického modelu AVISO („Agrometeorologická Výpočetní a Informační Soustava“) na ČHMÚ, pobočce Brno. Model je svou podstatou určen pro analýzu př́padů s převládajicím nedostatkovým množstvím srážek. Neřeší tedy problematiku nadbytku srážek a s tím spojenou otázku odtoku. Z tohoto pohledu se naskýtá jeho uplatnění pro analýzu existujících suchých období, resp. období, kdy se vyskytují minimální úhrny srážek.

Evapotranspirace je modelově počítána $v$ denním kroku modifikovaným postupem podle algoritmů Penman-Montheith [21, 22]. Ve své potenciální podobě je prakticky shodná s maximálně možnými hodnotami výparu při optimálních vláhových podmínkách, s nimiž se v přírodním prostředí většinou nesetkáváme ve vegetačním období, resp. v teplém půlroce, ale podstatně častěji v zimě nebo v obdobích prechodných (jaro a podzim).

ZVB_TP jednoduchým způsobem vyjadřuje vláhové poměry $v$ krajině za určitý časový interval. Počítá se jako aritmetický rozdíl srážek a evapotranspirace (potenciální, aktuální, referenční) za určité časové období, přičemž obě složky pro lepší vzájemné srovnání se vyjadřují v mm. Pro zjednodušení se neberou v úvahu žádné ze složek odtoku, stejně tak pro výpočet výparu v základní bilanční rovnici uvažujeme výrazné zjednodušení ve formě homogenního vypařujícího povrchu, který je svými fyziologickými vlastnostmi velmi blízký standardnímu travnímu porostu. Pokud bychom nepristoupili k těmto zjednodušením, problematika vláhových bilancí, která je v prírodních podmínkách velmi náročná a složitá, by z pohledu krajiny jako celku byla prakticky neřešitelná. S ohledem na prístupnost vody v půdě pro rostliny vyjadřujeme zásobu využitelné vody $\vee$ metrové vrstvě pưdy s travním porostem (dále jen ZVVP), která je vypočtena přepočtem $\mathrm{VVK} \vee \%$ [23].

\section{VÝSLEDKY}

Průběh sucha v jednotlivých letech na našem území není zcela stejný. Již bylo uvedeno, že v našich podmínkách jde o sucho nahodilé. Pokud jde o rok 2012, výrazně negativní potenciální vláhová bilance byla zvláště v měsících vegetačního období roku 2012. Srovnáním s dlouhodobým obdobím let 1961-2010 navíc docházíme k závěrům zvýšené negativní potenciální vláhové bilance. Tato skutečnost byla zaznamenána i při hodnocení pomocí kumulovaných úhrnů. Prokazatelné je to hlavně na moravských stanicích (Brno-Tuřany, Kuchařovice) a $v$ Doksanech, kdy proti dlouhodobým měsičním hodnotám je situace $v$ roce 2012 o více než 50 mm horší (květen). Bereme-li v úvahu kumulované úhrny po měsících, pak ve vegetačním období je situace ještě horší, nebot' oproti dlouhodobým poměrům do vyrovnané potenciální vláhové bilance schází i více než 200 mm (jižní Morava).

Zvláště pro zemědělské porosty bylo negativní, že v posledním týdnu května 2012 byl rozdíl oproti dlouhodobé hodnotě -100 mm a byl nižší na více jak 30 \% území ČR. Nejvíce jsou opět postiženy jižní a střední Morava, dále Polabí, část Poohří a také plošně velké oblasti jihozápadních Čech a Šumavy. Vláhovou bilanci pod -100 mm už je možno považovat za mimořádné sucho. Pod -150 mm je na 3,5 \% území, nejvíce na jižní Moravě, části Šumavy a na Přerovsku. Suchem v roce 2012 byla nejvíce zasažena jižní a střední Morava a výrazné negativní rozdíly přetrvávaly i v Polabí a na Šumavě. Na většině území byla negativní vláhová bilance ještě koncem září a místy překračovala hodnoty -200 mm.

Bylo by chybou posuzovat sucho samostatně jen v určitých měsících. Jeho vývoj je ovlivňován i průběhem počasí v zimě. Dokladem je výskyt sucha v roce 2015. Zima 2014/2015 jako celek byla oproti průměru na celém území teplejší, a to 01,5 až $3,5^{\circ} \mathrm{C}$. Deficit srážek dosahoval až $50 \%$, na některých částech jižní Moravy a na větší části Čech. Jen na částech severní a východní Moravy byl

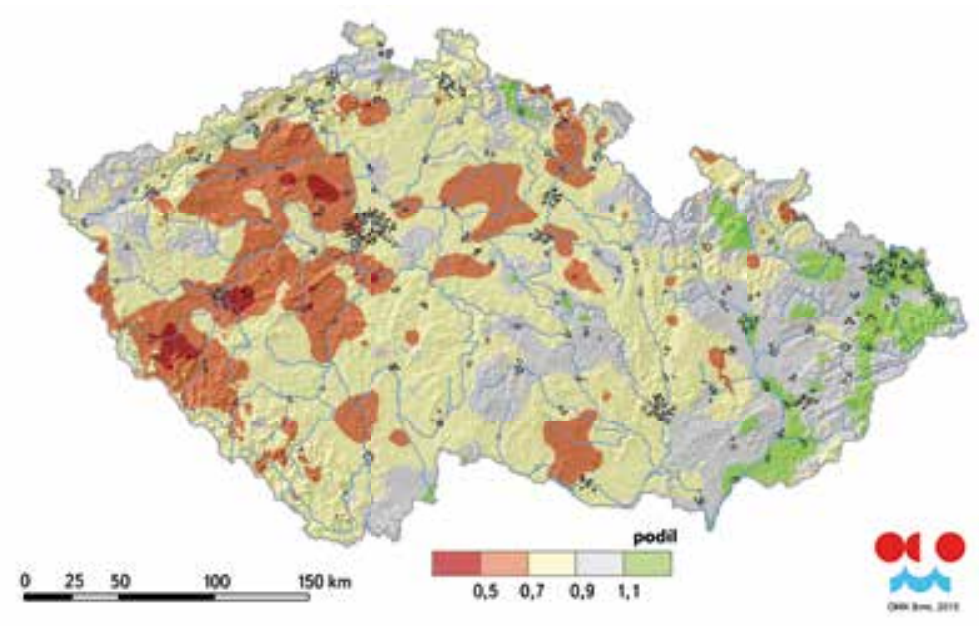

Obr. 1. Podíl srážkového úhrnu za zimu 2014/2015 vzhledem k dlouhodobému průměru 1961-2000

Fig. 1. Ratio between precipitation amount and long-term average (1961-2000) for the 2014/2015 winter

o něco vyšší než průměr (obr. 1). V průběhu měsíců dubna až června byly úhrny srážek na většině našeho území podnormální, takže koncem května v pásu od Karlových Varů přes střední Čechy až k Českým Budějovicím se jejich úhrn pohybuje mezi 50 až 75 \% průměru. Obdobně je to na jižní a části střední Moravy. Tento stav se v červnu mění tak, že v Podkrušnohoří dochází k dorovnání průměru, naopak na Moravě se zvyšuje plocha území s deficitem srážek mezi 25 až 50 \%. Mimořádně nízké úhrny srážek v červenci zpưsobují, že na většině našeho území byl deficit 25 až 50 \%. Na několika místech, hlavně v oblasti jižní Moravy, je srážkový deficit více jak 50 \%. Ovšem díky bouřkám jsou na těchto územích lokality, kde deficit srážek poklesl. Prohlubující se deficit v srpnu zastavily až srážky od 16. srpna. Na obr. 2 je srovnání úhrnů srážek od 1. 1. do 13. 12. 2015 s průměrem za roky 1961 až 2000 v procentech.

Díky těmto podmínkám dosahovaly hodnoty základní vláhové bilance v březnu průměrných hodnot, tomuto odpovídala i ZVVP v půdním horizontu. Průběh teplot vzduchu v dubnu vyvolával zvýšení hodnot evapotranspirace asi na polovině území Čech o $20 \%$, ale místy až o více než $40 \%$. Výskyt tropických veder zvyšuje deficit tak, že ke dni 12. 7. jsou místa, kde základní vláhová bilance má hodnoty pod -150 mm. Tento stav je po celý červenec s tím, že nehomogenitu tohoto pole způsobují lokální bouřky. Ovšem jejich ojedinělý výskyt neovlivňuje celkovou vláhovou bilanci, takže $v$ polovině srpna překračuje na asi čtvrtině našeho území deficit hodnoty -200 mm. Přes výskyt srážek byly projevy zemědělského sucha na převážné části našeho území ještě v řínnu. Na severní Moravě potom až do konce roku 2015.

Jako mimořádně suchý se opět projevil na mnoha místech našeho území i rok 2017. Jak již bylo mnohokrát uvedeno, základem obsahu vody v půdě pro počátek vegetačního období jsou stavy počasí v průběhu zimy. Pokud jde o srážky, byly tyto za měsíce leden až březen na převážné části území Moravy, jižních a východních Čech v rozpětí 50 až 75 \% dlouhodobého průměru, tedy podprůměrné. Na prevážné části Čech potom činily 75 až 90 \%, na některých místech odpovídaly dlouhodobému průměru. Ovšem díky nadprůměrným hodnotám teploty vzduchu dosahuje potenciální evapotranspirace $v$ březnu na takřka celém území Moravy a Slezska přes $140 \%$ oproti dlouhodobému průměru a v Čechách je to na více jak polovině území, jde převážně o střední a východní část Čech. ZVB_TP je za březen takřka na celém území v rozpětí od nuly po $-50 \mathrm{~mm}$. 


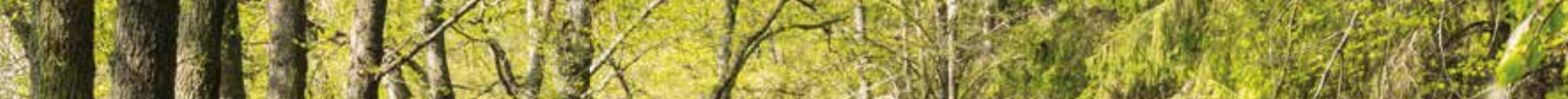

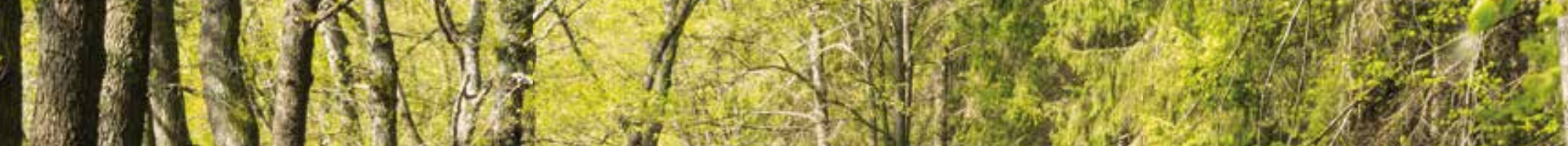

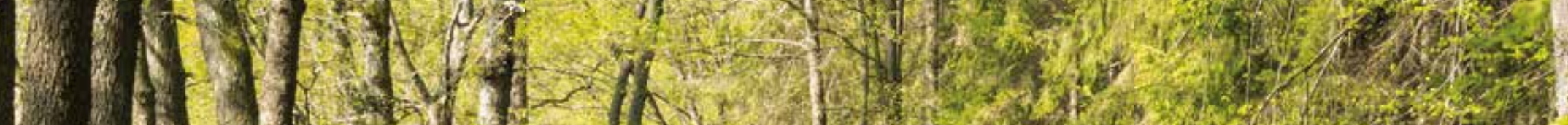
1 - 1 (n)

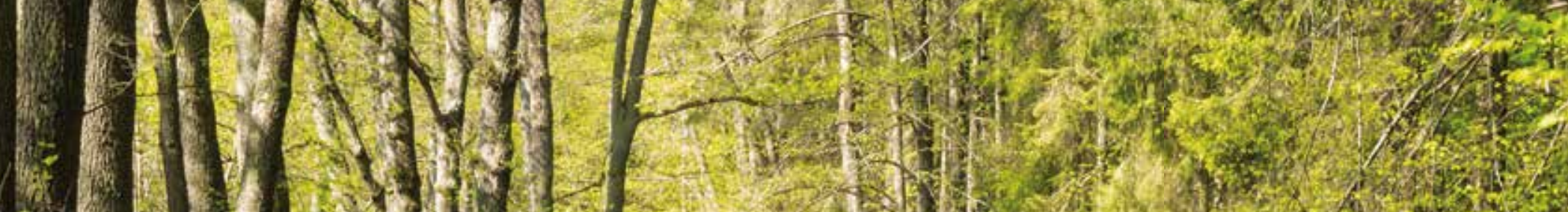

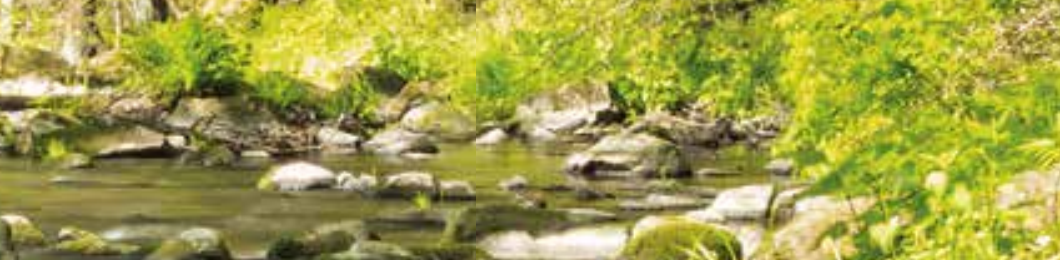

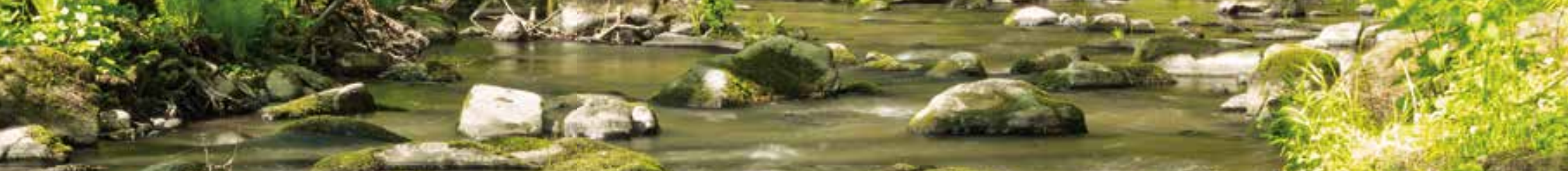

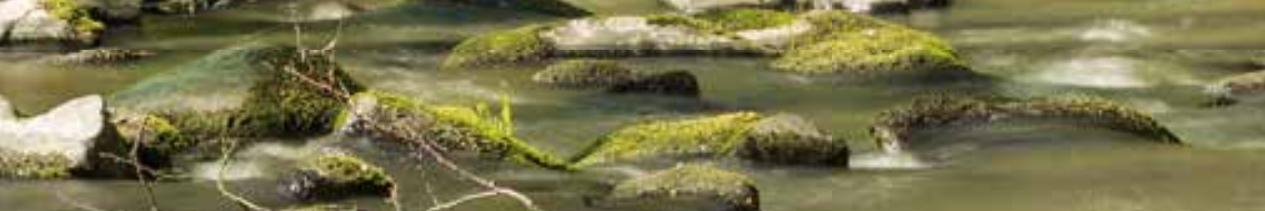
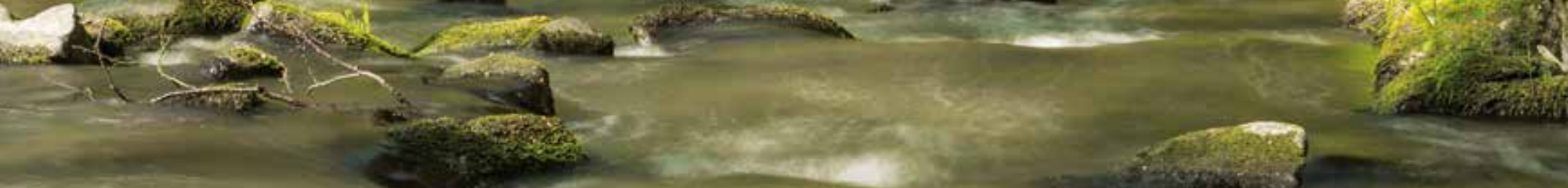


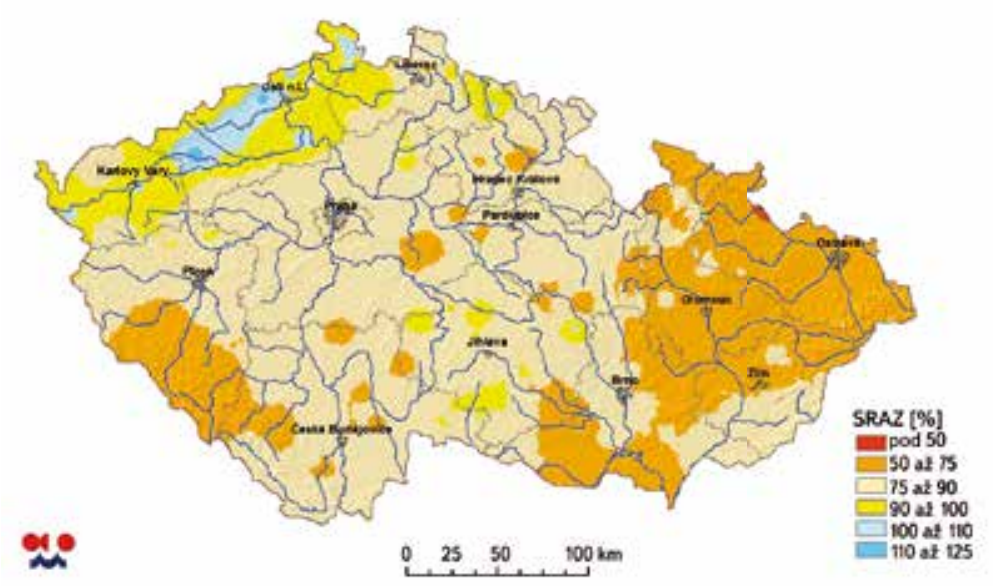

Obr. 2. Mapa srovnání úhrnů srážek za období 1. 1. až 13. 12. 2015 s průměrem za roky 1961-2000 vyjádřeného v \% (zdroj: ČHMú)

Fig. 2. Map comparing precipitation amount from Jan 1 to Dec 13, 2015 with the long-term average (1961-2000) expressed in \% (source: CHMI)

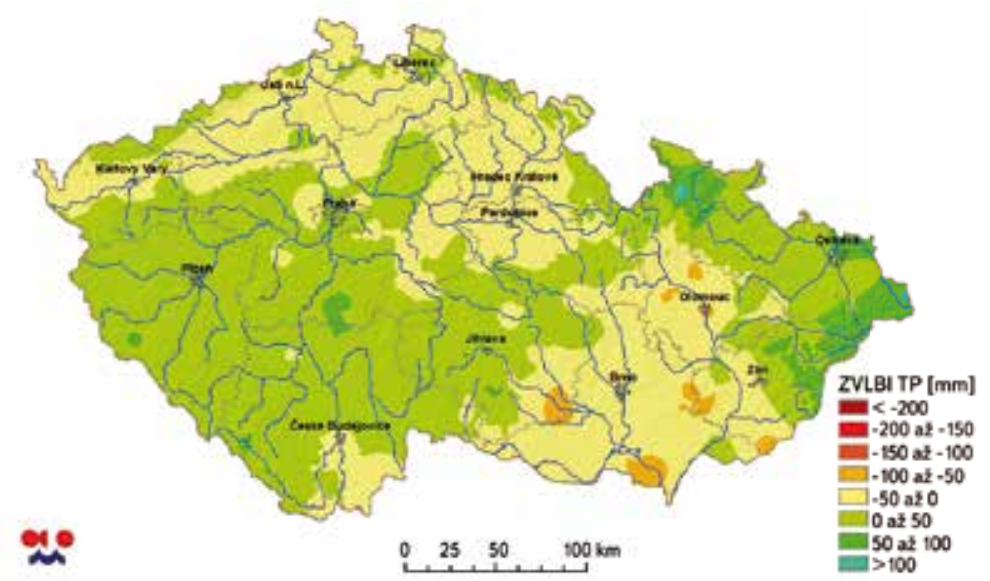

Obr. 3. Základní vláhová bilance území ČR (\%), srovnání stavu od 1. 3. do 21. 5. 2017 k dlouhodobému průměru 1961 až 2010 (http://portal.chmi.cz/aktualni-situace/sucho\#) Fig. 3. Basic water balance in the Czech Republic (\%), comparison of values from Mar 1 to May 21, 2017 with the long-term average (1961-2010) (http://portal.chmi.cz/aktualni-situace/sucho\#)

Jestliže bereme duben jako první měsíc vegetačního období, potvrzuje se že na jižní Moravě je duben často suchý. Plošná rozdílnost projevư počasí se $\checkmark$ dubnu potvrdila. Díky nepravidelnému rozložení srážek, místy velmi nízkému, dochází v průběhu května k velkým rozdílům v hodnotách ZVB_TP. Je to dáno oproti průměru vyšší potenciální evapotranspirací na převážné části našeho území, místy přesahující 140 \% dlouhodobého průměru. Nacházíme místa se srážkami k 150 \% a naopak pouze k 50 \% procentům oproti průměru.

Pritom dostatek vody má pro většinu zemědělských plodin rozhodující význam. Jak vidíme na obr.3, dochází v prvních třech týdnech května 2017 k deficitu ZVB_TP až k -100 mm na některých místech jižní a severní Moravy. V Čechách je od Podkrušnohoři pres severní oblasti až po východní Čechy stav mezi průměrem až -50 mm. Naopak od Prahy na jih a na severní Moravě je bilance kladná.

Nadprůměrné teploty v průběhu června a velmi rozdílné, ale převážně podprůměrné úhrny srážek však způsobují, že koncem června jsou místy hodnoty ZVB_TP na jihu Moravy, ale i Čech pod -100 mm, lokálně pod -150. Na jižní a střední části Moravy mají hodnoty pod $25 \%$, podobně jako dílčí územi v Podkrušnohoří. Naopak střední Čechy v pásu až ke Krkonoším mají hodnoty

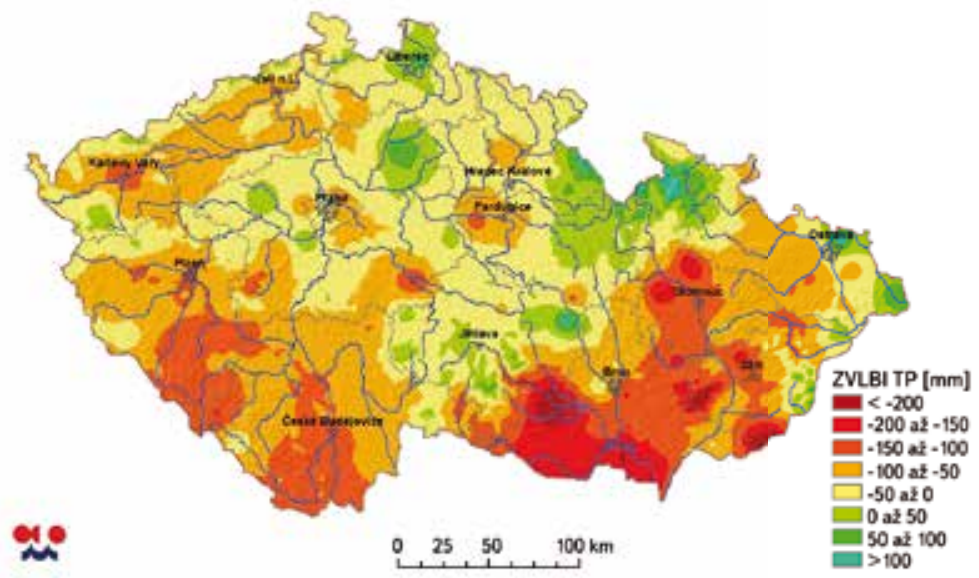

Obr. 4. Základní vláhová bilance území ČR (\%), srovnání stavu od 1. 3. do 30. 7. 2017 k dlouhodobému průměru 1961 až 2010 (http://portal.chmi.cz/aktualni-situace/sucho\#) Fig. 4. Basic water balance in the Czech Republic (\%), comparison of values from Mar 1 to Jul 30, 2017 with the long-term average (1961-2010) (http://portal.chmi.cz/aktualni-situace/sucho\#)

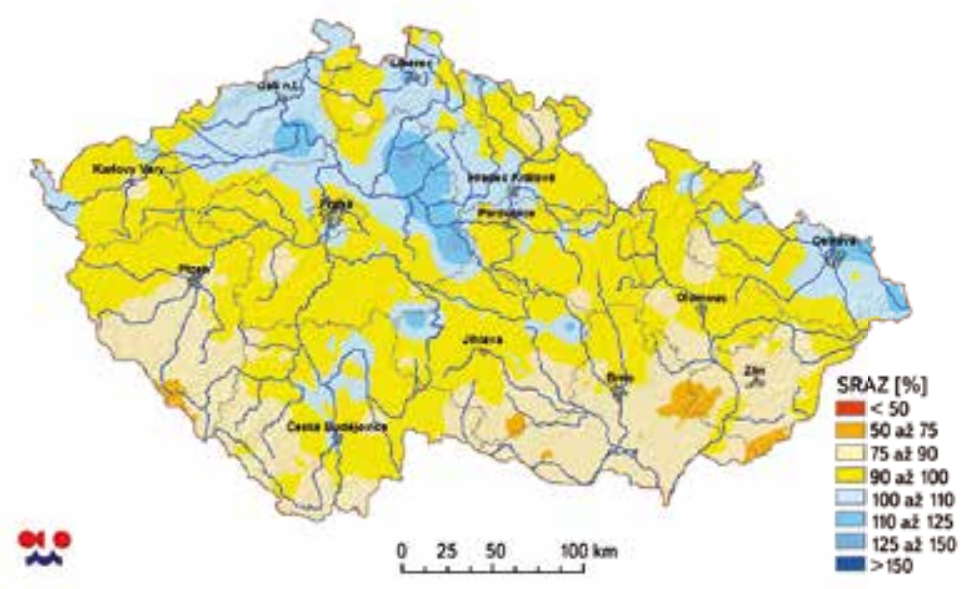

Obr. 5. Rozložení úhrnů srážek na území ČR za období 1. ledna až 1. října 2017

(http://portal.chmi.cz/aktualni-situace/sucho\#)

Fig. 5. Precipitation distribution in the Czech Republic from Jan 1 to Oct 1, 2017 (http://portal.chmi.cz/aktualni-situace/sucho\#)

průměrné, místy až několik desítek nad dlouhodobým průměrem. V červenci jsou srážky srovnatelné s průměrem na většině území. Teploty vzduchu jsou vyšší od $1^{\circ} \mathrm{C}$ až pres $2^{\circ} \mathrm{C}$ na jihu Moravy. Tím je dáno, že na většině území jsou hodnoty ZVB pod $-100 \mathrm{~mm}$. Na prevážné části jižní a střední Moravy a v jižních Čechách jsou nižší jak -150, lokálně na jižní Moravě pod -200mm. Ovšem v některých oblastech, zvláště na severu Moravy je ZVB_TP v hodnotách průměru. Lokálně jsou tyto hodnoty i v Čechách (obr. 4).

Srpen má úhrny srážek významně rozdílné v Čechách, kde jsou např. na západě, ale i v jižních Čechách až o 50 \% vyšší než průměrné, ovšem na většině území Moravy a Slezska je to jen mezi 50 až 70 \%. Ale teploty vzduchu jsou zde vyšší o více než $2^{\circ} \mathrm{C}$ nad průmèrem, kdežto na západě Čech je to jen do $+1,5^{\circ} \mathrm{C}$. Výsledek je jasný. Hodnoty potenciální evapotranspirace jsou na převážné části republiky nadprůměrné.

Mínusové hodnoty ZVB se prohlubují, takže deficit nižší než 200 mm je na větších plochách, mají ho lokality na střední i severní Moravě. Hodnoty pod -150 mm nacházíme v celé jižní části republiky, ale také na Karlovarsku. Pokud jde o ZVVP, je víceméně stejná situace jako v červnu, tedy na jižní a střední 
Moravě jsou hodnoty stále pod 25 \%, podobně jako dílči území v Podkrušnohoří a na jihovýchod od Plzně. Mírně se zmenšila oblast s průměrnou hodnotou ve středních Čechách, ale v pásu u Podkrkonoší zůstávají místa s hodnotami ZVVP u středních půd až několik desítek \% nad dlouhodobým průměrem. Podobně je tomu v oblasti Jeseníků a severovýchodních Beskyd.

Výskyt vydatných srážek na počátku zárí z části snižil vláhový deficit. Takřka na třetině území Čech byl v polovině zárí dosažen, popř. i překročen, dlouhodobý průměr srážkových úhrnů k 1. 10. 2018 (obr. 5). Na Moravě pouze v jižní a střední části byly oblasti s úhrny mezi 50 až $75 \%$ průměru. Dochází tak ke zlepšení ZVB, když na severní části Čech a Moravy má hodnoty dlouhodobého průměru. Ovšem na jižní a střední Moravě, ale i v jižních Čechách jsou stále katastry, kde chybí více jak 200 mm. V těchto je i ZVVP nízká, pohybuje se mezi 25 až 50 \%. Tyto hodnoty nacházíme i v okolí Prahy. Pokračující výskyty srážek pozvolna vylepšují množství vody v půdě v konci vegetačního období, tedy koncem září. Jen na Moravě se nachází několik míst, kde je výskyt srážek mezi 50 až $75 \%$ průměru. V Čechách je na sever od Prahy výskyt přes $100 \%$, podobně na severovýchodě Moravy. Ovšem ZVB_TP se zlepšuje jen nepatrně, v podstatě se od poloviny září výrazně nemění.

\section{ZÁVĚR}

Při hodnocení množství vody v naší krajině musíme brát v úvahu, že extrémy ve výskytu srážek jsou v posledních letech stále dynamičtější. Prokazatelný je rưst teploty vzduchu za období 1961 až 2010, ale naopak je statisticky potvrzený setrvalý stav ročních úhrnů srážek. Z těchto poznatků vyplývá, že se může zvyšovat četnost výskytů sucha, což uvedená hodnocení dokládají.

Potvrzuje se, že hodnoty základní vláhové bilance a zásoby využitelné vody $\checkmark$ metrové vrstvě půdy s travním porostem jsou vhodným ukazatelem určení výskytu sucha a hodnocení jeho intenzity. Předložené výsledky potvrdily, že území ČR je z hlediska vláhové bilance velmi rozdílné. Vliv na toto rozložení má proměnlivý výskyt srážek, ale také hodnoty teploty vzduchu, které jsou v suchých letech, hlavně v letním období, mimořádně vysoké. Sucho má určitý kumulativní charakter, $v$ nepríznivých podmínkách se jeho intenzita a dopady s každým dnem zvyšují. Následky potom mohou trvat dlouhou dobu po jeho ukončení.

Nástupy sucha i místa výskytu jsou v závislosti na srážkách proměnlivé, ale přesto můžeme uvést, že se sucho nejčastěji vyskytuje v našich nejteplejších oblastech s nejnižšími ročními úhrny srážek. Z hlediska udržení srážkové vody $\checkmark$ naší krajině jsou dưležité vlastnosti našich pưd jak zemědělských, tak lesnických, na kterých hlavně probíhá vsakování. Proto je důležité príijetí opatření pro zlepšení infiltrační schopnosti a zvýšení retenční kapacity těchto půd do původního stavu.

Souvisí s tím i opatření pro snížení eroze půdy, protože orniční horizont má tuto kapacitu významně vyšší než na erodovaných půdách, kde horní vrstvu tvoří podorničí. Zvýšení členitosti naší krajiny přispěje ke snížení odtoku vody.

Podle výsledků klimatologických modelů by mohlo dojít ke vzrůstu průměrných ročních teplot koncem tohoto století až o více než dva stupně, ale srážkové úhrny budou víceméně shodné se současnými. Z toho plyne jeden významný poznatek, že na našem území by se mohly významně snižovat hodnoty vláhové bilance, a to znamená zvyšování jak intenzity, tak četností výskytu sucha. Pro snížení negativních dopadů změn klimatu bychom měli konat preventivní kroky, aby se nedostatek vody nestal bezpečnostním rizikem.

\section{Poděkování}

Príspěvek byl vypracován s podporou projektu NAZV registrační čislo QK1720285 „Metody korekce vláhových potřeb plodin zohledñujici scénáre změn klimatu území ČR pro optimalizaci managementu závlah".

Tento článek byl zpracován na základě příspěvku, který byl publikován ve sborníku konference Vodní nádrže 2017, ISBN 978-80-905368-5-2.

\section{Literatura}

[1] ŽIDEK, D. a LIPINA, P. Návod pro pozorovatele meteorologických stanic ČHMÚ. Metodický předpis č. 13, Ostrava: ČHMÚ, 2003. 90 s.

[2] TOLASZ, R. a kol. Atlas podnebí Česka. ČHMÚ, Univerzita Palackého v Olomouci, 2007, 255 s. ISBN 978-80-86690-26-1 (CHMI), 978-80-244-1626-7 (UP).

[3] STŘEŠTÍK, J., ROŽNOVSKÝ, J., ŠTĚPÁNEK, P. a ZAHRADNIČEK, P. Změna ročních a sezonních srážkových úhrnů v České republice v letech 1961-2012. In: Extrémy oběhu vody v krajině, Mikulov, 2014 b. (CD-ROM).

[4] BRUTSAERT, W. Evaporation into the Atmosphere. Dordrecht: D. Reidel Publishing Co., 1982, p. 299.

[5] KŘíž, H. Výpar v povodí Moravy a Horní Odry. In: Sborník prací Hydrometeorologického ústavu Československé socialistické republiky. Praha: ČHMÚ, 1966, sv. 8, s. 34-58.

[6] BUCHTELA, Š. Výparoměrná stanice Hlasivo. In: ROŽNOVSKÝ, J. a LITSCHMANN, T. Seminár̆ „Evaporace a evapotranspirace" [online]. [cit. 16. 8. 2011]. 2005. Dostupné z: http://cbks.cz/sbornik05/prispevky.htm

[7] ALLEN, R.G. and PRUITT, W.O. FAO-24 reference evapotranspiration coefficients. Journal Irrig. and Drainage Engineering, ASCE vol. 117, No. 5, 1991, p. 758-773.

[8] KNOZOVÁ, G., ROŽNOVSKÝ, J. a KOHUT, M. Srovnaní časových řad výparu naměřeného výparoměrem GGI-3000 a vypočitaného podle metodiky FAO. In: ROŽNOVSKÝ, J. a LITSCHMANN, T. (ed): Bioklimatologie současnosti a budoucnosti. Křtiny 12.-14. 9. 2005. Dostupné z: http://www.cbks.cz/ sbornik05b/KnozovaRoznovskyKohut.pdf

[9] LAPIN, M. Zhodnocení výparu GGI-3000 na Slovensku za období 1969-1973. Meteorologické Zprávy, 1977, roč. 30., Č. 6, s. 168-174. ISSN 0026-1173.

[10] KOHUT, M., ROŽNOVSKÝ, J., KNOZOVÁ, G. a BRZEZINA, J. Měrení výparu z vodni hladiny automatizovaným výparoměrem EWM v České republice. Práce a studie. Praha, 2016.

[11] MONTEITH, J.L. and UNSWORTH, M.H. Principles of Environmental Physics. London: Edward Arnold, 1990. $2^{\text {nd }}$ ed., p. 291.

[12] KOHUT, M., ROŽNOVSKÝ, J. a KNOZOVÁ, G. Měření výparu z vodni hladiny výparoměrem GGI-3000 vCeské republice. Práce a studie 35. Praha: ČHMÚ, 2013, 95 s. ISBN 978-80-87577-16-5. ISSN 1210-7557.

[13] STŘEŠTÍK, J., ROŽNOVSKÝ, J., ŠTĚPÁNEK, P., and ZAHRADNÍČEK, P. Increase of annual and seasonal air temperatures in the Czech Republic during 1961-2010. In: ROŽNOVSKÝ, J. and LITSCHMANN, T. eds. Mendel and Bioclimatology. Conference proceedings, Brno, $3^{\text {rd }}-5^{\text {rd }}$ Sep. 2014 [CD-ROM]. Brno: 2014. ISBN 978-80-210-6983-1.

[14] ALLEN, R.G., PEREIRA, L.S., RAES, D., and SMITH, M. Crop evapotranspiration. Guidelines for computing crop water requirements. Food and Agriculture Organization. FAO Irrigation and Drainage Papers, 1998, No. 56, p. 301.

[15] BOS, M.G., VOS, J., and FEDDES, R.A. CRIWAR 2.0. A simulation model on Crop Irrigation Water Requirements. Wageningen: ILRI publication 46, 1996, p. 117.

[16] PENMAN, H.L. Natural evaporation from open water, bare soil and grass. Proceedings of the Royal Society of London. Series A, 1948, vol. 193, No. 1032, p. 120-145

[17] ROŽNOVSKÝ, J. a kol. Agroklimatologická studie o výskytu sucha na území ČR v roce 2012 a za období srpen 2011 až srpen 2012. Zpráva pro Výzkumný ústav meliorací a ochrany pưdy. Brno: ČHMÚ, pobočka Brno, 2012, $67 \mathrm{~s}$.

[18] KURPELOVÁ, M., COUFAL, L. a ČULÍK, J. Agroklimatické podmienky ČSSR. Bratislava: Hydrometeorologický ústav, $1975.270 \mathrm{~s}$.

[19] DOORENBOS, J. and PRUITT, W.O. Guidelines for Predicing Crop Water Reqiurements. Rome: FAO Irrigation and Drainage Paper 24, $2^{\text {nd }}$ ed. FAO, 1977, p. 156

[20] VOPRAVIL, J. a kol. Pưda a její hodnocenív ČrR. Díl I. Výzkumný ústav meliorací a ochrany půdy, v. v. i., Praha, 2. vydání, 2010. 147 s. ISBN 978-80-87361-05-4.

[21] BURMAN, R. and POCHOP, L.O. Evaporation, Evapotranspiration and Climatic Data. Amsterdam: Elsevier Science B. V., 1994. p. 275.

[22] ŠTĚPÁNEK, P. and ZAHRADNIČEK, P. Experiences with quality control and homogenization of daily series of various meteorological elements in the Czech Republic, 1961-2007. In: Proceedings of the Sixth seminar for homogenization and quality control in climatological databases (Budapest, 25.-30. May 2008), WCDMP, WMO, Genova. 2008

[23] NOVÁK, V. Vyparovanie vody v prírode a metódy jeho určovania. Bratislava: SAV, 1995. 260 s. 


\section{Autoři}

RNDr. Ing. Jaroslav Rožnovský, CSc. ${ }^{1,2}$

凶roznovsky@chmi.cz

RNDr. Filip Chuchma'

凶filip.chuchma@chmi.cz

Ing. Rostislav Fiala ${ }^{1}$

凶rostislav.fiala@chmi.cz

RNDr. Mojmír Kohut, Ph.D. ${ }^{1}$

凶mojmir.kohout@chmi.cz

'Český hydrometeorologický ústav, pobočka Brno ${ }^{2}$ Mendelova univerzita $v$ Brně, Zahradnická fakulta

Příspěvek prošel lektorským řízením.

\section{WATER BALANCE - EXPRESSION OF THE AMOUNT OF WATER IN LANDSCAPE}

\section{ROZNOVSKY, J. ${ }^{1,2}$; CHUCHMA, F. ${ }^{1}$; FIALA, R. ${ }^{1}$; KOHUT, M. ${ }^{1}$}

${ }^{1}$ Czech Hydrometeorological Institute, Brno Branch ${ }^{2}$ Mendel University in Brno, Faculty of Horticulture

Keywords: water balance - precipitation amount potential evapotranspiration - drought

Course of the weather in the last years shows that variability of the weather increases and this also leads to a higher frequency of floods, as well as drought. Drought, regardless of its type, means that there is a lack of water in landscape. The question is how to express the amount of water in landscape in the most suitable way. The Brno branch office of the Czech Hydrometeorological Institute uses the AVISO model to calculate basic water balance in weekly steps for grassland, expressed by the difference between precipitation amount and potential evapotranspiration. The calculation uses daily values of sunshine duration, air temperature and humidity and wind speed. The basic assumption of extraordinary drought is low precipitation amount and longer periods without rain. However, high air temperatures also have an effect. Analysis of years with extraordinary drought shows that the course of water balance deficit is different in each year. By the end of vegetation period the deficit is even over $200 \mathrm{~mm}$. 